\title{
Rhizome rot of ginger-management through non-chemical approach
}

\author{
ANIL THAKUR ${ }^{1}$, NISHA THAKUR* AND N.P. DOHROO ${ }^{1}$
}

Department of Biotechnology, Dr. Y. S. Parmar University of Horticulture and Forestry, SOLAN (H.P.) INDIA ${ }^{1}$ Department of Mycology and Plant Pathology, Dr. Y. S. Parmar University of Horticulture and Forestry, SOLAN (H.P.) INDIA

\section{ARITCLE INFO}

Received : 18.02 .2017

Revised : 20.03 .2017

Accepted : 24.03 .2017

\section{KEY WORDS :}

Ginger, Rhizome rot,

Non-chemical management

*Corresponding author:

nishathakur81086@gmail.com

\begin{abstract}
Ginger (Zingiber officinale Rosc.) an important spice crop grown in different states of India especially Himachal Pradesh, a hilly area situated in northern Himalayas. Pythium and Fusarium are the main fungus which affect the crop in a drastic manner. Ginger rhizome diseases are both rhizome seed and soil borne and their chemical management leads to notorious effect on environment and ecosystem. Therefore, an attempt to work out for isolation of Pythium and Fusarium sp. (major pathogens causing ginger rot) from Sirmaur and Solan areas of the state and research emphasized on non-chemical management of these fungal diseases. Hot water treatment of ginger rhizomes at different temperatures excluded the maximum rhizome borne inoculum through eradication. Among the biocontrol agents $T$. harzianum was found more effective for pathogenic fungal inhibition recorded as $(50.28 \%)$ followed by $T$. hamatum $(44.94 \%)$ and Streptomyces sp. (40.11\%).
\end{abstract}

How to view point the article : Thakur, Anil, Thakur, Nisha and Dohroo, N.P. (2017). Rhizome rot of ginger-management through non-chemical approach. Internat. J. Plant Protec., 10(1) : 140145, DOI : 10.15740/HAS/IJPP/10.1/140-145. 